\title{
СИНТЕЗ Na-СОЛЕИ АЛКИЛАМИНОЭТАНСУЛЬФОКИСЛОТ НА ОСНОВЕ ОЛЕФИНОВОГО СЫРЬЯ
}

\begin{abstract}
D. ROIZ, S. FAINGOLD, Rutt TOMSON. ALKOOLAMINOETAANSULFOHAPETE NAATRIUMISOOLADE SUNTEES OLEFIINSE TOORAINE POHJAL

D. ROIZ, S. FAINGOLD, RUtT TOMSON, SYNTHESIS OF ALKYLAMINOETHANESULPHONATES FROM TECHNICAL OLEFINS
\end{abstract}

(Представил О. Эйзен)

Исследованием ['] установлены высокие поверхностно-активные свойства $\mathrm{Na-coлей} \mathrm{алкиламиноэтансульфокислот.} \mathrm{Эти} \mathrm{вещества} \mathrm{обладают} \mathrm{также}$ высокой диспергирующей способностью в отношении Са-мыл, что обуславливает возможность их использования в бесфосфатных моющих композициях. Они не оказывают заметного раздражающего действия на кожу и биологически окисляются. В данной работе изучалась возможность получения $\mathrm{Na}-$ солей алкиламиноэтансульфокислот общей формулы $\mathrm{R}-\mathrm{CH}\left(\mathrm{CH}_{3}\right)-\mathrm{NHCH}_{2} \mathrm{CH}_{2} \mathrm{SO}_{3} \mathrm{Na}$, на основе доступного олефинового сырья. Представляет интерес использование хлоралканов, которые можно получать в промышленных масштабах из олефинового сырья путем выделения узких фракций с последующим гидрохлорированием.

Нами были синтезированы 2-хлорпарафины из индивидуальных реактивных олефинов - децена и додецена, а также из узких технических фракций олефинов крекинга парафинов. Олефины гидрохлорируют газообразным $\mathrm{HCl}$ в присутствии хлоридов металлов $\left(\mathrm{ZnCl}_{2}, \mathrm{FeCl}_{3}\right.$, $\left.\mathrm{BiCl}_{3}, \mathrm{TiCl}_{4}\right)$, растворенных в полярных растворителях [ $\left.{ }^{2}\right]$. Хорошие выходы 2-хлоралканов получаются в присутствии $\mathrm{ZnCl}_{2}$, растворенного в сульфолане. Количество катализатора по отношению к олефину составляет 20-30 масс. \%. Присоединение $\mathrm{HCl}$ к олефинам крекинга парафинов затруднено наличием примесей диолефинов, циклоолефинов, ароматики и парафинов [3]. Примеси вызывают побочные реакции, значительно снижающие выходы и качество продуктов синтеза, увеличивают расход катализаторов [4]. При гидрохлорировании технической фракции конверсия олефинов значительно снижается по сравнению с аналогичным опытом гидрохлорирования индивидуальных олефинов. Хроматографический анализ показывает наличие значительного количества непревращенных олефинов. Техническая фракция олефинов должна быть предварительно очищена от циклоолефинов, диолефинов и возможных малых количеств сернистых соединений. Очищенную узкую фракцию олефинов гидрохлорируют по методике, применяемой для индивидуальных олефинов. Взаимодействие вторичных хлорпара-

6 ENSV TA Toimetised. K 21981 
финов с Na-солью таурина осуществляется в среде высококипящего растворителя, например, в бензиловом спирте, при атмосферном давлении, или в автоклаве.

\section{Экспериментальная часть}

Синтез 2-хлоралканов из индивидуальных олефинов. Через смесь олефина (децена-1 или додецена-1) и $\mathrm{ZnCl}_{2}$, растворенного в сульфолане, барботируют сухой $\mathrm{HCl}$ в течение $3-4$ ч при температуре $80-90{ }^{\circ} \mathrm{C}$. Количество катализатора по отношению к олефину составляет 20-30 масс. \%. По окончании реакции смесь охлаждают, при этом реакционная масса расслаивается. Верхний слой, содержащий хлоралкан, отделяют, промывают водой и сушат $\mathrm{CaCl}_{2}$. Определяют содержание хлора в продукте (см. табл.). По данным хроматографического анализа и по анализу на содержание хлора можно заключить, что полученный сырой продукт представляет собой практически чистый 2-хлоралкан.

Содержание хлора в продуктах гидрохлорирования и конверсия олефинов

\begin{tabular}{l|l|l|l}
\hline \multirow{2}{*}{ 2-Хлоралкан } & \multicolumn{2}{|c|}{ Содержание хлора, \% } & $\begin{array}{c}\text { Конверсия } \\
\text { олефина, \% }\end{array}$ \\
\cline { 2 - 3 } & теоретич. & практич. & \\
\hline
\end{tabular}

$\begin{array}{llll}\text { 2-Хлордекан } & 20,1 & 19,8 & 98,5 \\ \text { 2-Хлордодекан } & 17,3 & 16,8 & 97,0 \\ \text { 2-Хлортетрадекан } & 15,3 & 11,9 & 78,0 \\ \text { 2-Хлорпентадекан } & 14,4 & 10,9 & 76,0\end{array}$

Очистка узких технических фракций олефинов. Фракции олефинов $\left(\mathrm{C}_{14}\right.$ и $\left.\mathrm{C}_{15}\right)$ обрабатывают $\mathrm{ZnCl}_{2}$ в количестве $10-20$ масс. \% при температуре $50-70^{\circ}$ в течение 1 . Затем $\mathrm{ZnCl}_{2}$ отделяют, а фракцию перемешивают с двухкратным количеством диэтиленгликоля в течение 0,5 ч при $50-60^{\circ}$. Гликоль отделяют, фракцию промывают водой и сушат $\mathrm{CaCl}_{2}$.

Гидрохлорирование узких технических фракций олефинов осуществляется по методике, применяемой для индивидуальных олефинов. Температура процесса $90-100^{\circ}$ и длительность 5-7 4 . После окончания реакции продукт промывают, сушат и определяют содержание хлора (см. табл.). Полученные технические 2-хлортетрадекан и 2-хлорпентадекан идентифицировались хроматографически.

Реакция 2-хлордекана и 2-хлордодекана с таурином в среде бензилового спирта. В 200 мл 80\% этанола растворяют 0,5 M Na-соли таурина. Прибавляют 150 мл бензилового спирта и отгоняют этанол и воду до температуры $120^{\circ}$. 0,2 M 2-хлоралкана дозируют в реакционную смесь и кипятят при $135-140^{\circ}$ в течение $20 \varkappa$. Смесь охлаждают, добавляют 30 мл воды и помещают в делительную воронку. Нижний слой содержит таурин и $\mathrm{NaCl}$. Слой бензилового спирта, содержащего алкиламиноэтансульфонат, промывают $2 \times 50$ мл гексана с целью удаления непрореагировавшего хлорида и продукта дегидрохлорирования. Раствор алкиламиноэтансульфоната в бензиловом спирте высушивают, сухое вещество промывают эфиром. Выходы 2-дециламиноэтансульфоната и 2-додециламиноэтансульфоната составляют $30-35 \%$ теоретического. 
Получение 2-тетрадецил- и 2-пентадециламиноэтансульфонатов в автоклаве. В качающийся автоклав загружают 100 мл 90\% этанола, 0,2 $M$ $\mathrm{Na-coли} \mathrm{таурина} \mathrm{и} 0,08 \mathrm{M}$ технического 2-хлорпарафина с содержанием основного вещества 76-78\%. Нагревают до $150-160^{\circ}$ в течение 8-10 ч, давление при этом поднимается до 5-6 атм. После охлаждения смеси прибавляют 80 мл этанола и 100 мл воды. Непрореагировавший 2-хлорпарафин экстрагируют 50 мл гексана. Спиртоводный раствор высушивают, сухое вещество растворяют в минимальном количестве горячей воды (около 300 мл) и экстрагируют 200 мл бутанола. Выходы 2-тетрадецил- и 2-пентадециламиноэтансульфонатов составляют $40-45 \%$ теоретического.

Примечание. 2-Тетрадецил- и 2-пентадецил-аминоэтансульфонаты могут быть получены также в среде высококипящих растворителей при атмосферном давлении; в свою очередь 2-децил- и 2-додециламиноэтансульфонаты можно синтезировать в автоклаве.

\title{
Выводы
}

Синтезированы индивидуальные вторичные децил- и додециламиноэтансульфонаты натрия и технические вторичные тетрадецил- и пентадециламиноэтансульфонаты. Показана возможность использования узких технических фракций олефинов крекинга парафинов для синтеза вторичных алкиламиноэтансульфонатов натрия.

\section{Л И Т Р А Т Р А}

1. Томсон Р., Файнгольд С., М аспанов Н. Коллоидно-химические свойства н-алкиламиноэтилсульфатов и -сульфонатов. - Изв. АН ЭССР, Хим. Геол., 1976 , т. 25 , № 3, с. $193-198$.

2. B akker, P. Preparation of Amino Detergents via Addition of Hydrocloric Acid to Long-Chain $\alpha$-Olefins. - Chem., Physik.-chem. und Anwendungstechnik der grenzflächenaktiven Stoffe. 6. Kongr. der grenzflächenaktiven Stoffe. Zürich, 1972 , Bd. 1, S. 325-336.

3. Гу ре в ич В. Р. и др. Производство и потребление высших линейных олефинов. Тематический обзор ЦНИИТЭНефтехим. М., 1978, с. 38-42.

4. Скляр В., Л ебеде в Е., 3 акупра В. Высшие моноолефины. Киев, 1964.

\author{
Ннститут химии \\ Академии наук Эстонской ССР
}

Поступила в редакцию 26/IX 1980 